Review

\title{
Dynamics of Axl Receptor Shedding in Hepatocellular Carcinoma and Its Implication for Theranostics
}

\author{
Elisa Holstein, Mathias Binder and Wolfgang Mikulits * $\mathbb{C}$ \\ Department of Medicine I, Division: Institute of Cancer Research, Comprehensive Cancer Center, \\ Medical University of Vienna, 1090 Vienna, Austria; elisa.holstein@meduniwien.ac.at (E.H.); \\ binder.mathias@imc-krems.eu (M.B.) \\ * Correspondence: wolfgang.mikulits@meduniwien.ac.at; Tel.: +43-1-40160-57527
}

Received: 28 November 2018; Accepted: 17 December 2018; Published: 18 December 2018

\begin{abstract}
Signaling of the receptor tyrosine kinase Axl and its ligand Gas6 is crucially involved in the development of liver fibrosis and hepatocellular carcinoma (HCC) by activation of hepatic stellate cells and modulation of hepatocyte differentiation. Shedding of Axl's ectodomain leads to the release of soluble Axl (sAxl), which is increased in advanced fibrosis and in early-to-late stage HCC in the presence and absence of cirrhosis. Here, we focus on the dynamics of Axl receptor shedding and delineate possible scenarios how Axl signaling might act as driver of fibrosis progression and HCC development. Based on experimental and clinical data, we discuss the consequences of modifying Axl signaling by sAxl cleavage, as well as cellular strategies to escape from antagonizing effects of Axl shedding by the involvement of the hepatic microenvironment. We emphasize a correlation between free Gas6 and free sAxl levels favoring abundant Gas6/Axl signaling in advanced fibrosis and HCC. The raised scenario provides a solid basis for theranostics allowing the use of sAxl as an accurate diagnostic biomarker of liver cirrhosis and HCC, as well as Axl receptor signaling for therapeutic intervention in stratified HCC patients.
\end{abstract}

Keywords: hepatocellular carcinoma; Axl; soluble Axl; Gas6; shedding; theranostics

\section{Key Events in HCC}

Hepatocellular carcinoma (HCC) represents the predominant type of primary liver malignancy showing the sixth most frequent incidence globally and the third most abundant cause of cancer mortality [1,2]. About $80 \%$ of HCC develop in the background of liver fibrosis and cirrhosis caused by chronic infection with hepatitis B or C virus (HBV, HCV), alcohol abuse or non-alcoholic fatty liver disease (NAFLD) / non-alcoholic steatohepatitis (NASH) [3]. Approximately 5-10\% of patients in Europe are diagnosed with HCC at the Barcelona Clinic Liver Cancer (BCLC) stage 0, referring to the very early stage of HCC, allowing curative therapy such as surgical resection or orthotopic liver transplantation $[4,5]$. Yet, the majority of HCC patients are diagnosed at advanced stages, which limits therapeutic options to treatment with the multikinase inhibitors sorafenib or regorafenib [6].

Deregulations of oncogenes and tumor suppressor genes by mutations and altered expression have been identified, although addictions to oncogenes for targeted therapeutic intervention or tumor suppressors by synthetic lethality approaches are still missing in HCC. Major driver mutations in HCC were identified in CTNNB1 ( $\beta$-catenin), telomerase reverse transcriptase, and TP53, among others, leading to aberrant Wnt signaling, chromosomal instability and escape from cell death $[7,8]$. Mutations of ARID1A, ARID2 and MLL1-4 further drive HCC by affecting chromatin regulation [9-11]. Moreover, transforming growth factor (TGF)- $\beta$ is a crucial factor in the development of HCC due to its 
pro-fibrotic and tumor-progressive functions [12,13]. Moreover, modulations of gene expression affect major regulators of HCC, such as c-myc, cyclin A2, cyclin D1, retinoblastoma 1, Axin1, insulin-like growth factor-II receptor/mannose-6-phosphate receptor, $\mathrm{p} 16^{\mathrm{INK} 4 \mathrm{a}}$, Yes-associated protein (YAP)1, E-cadherin, suppressors of cytokine signaling (SOCS), interleukin (IL)-6, phosphatase and tensin homolog, or cyclooxygenase 2 in HCC [14,15]. Notably, the expression of a large panel of receptor tyrosine kinases (RTKs) is increased, including ErbB receptors, fibroblast growth factor receptors, Met and its ligand hepatocyte growth factor, vascular endothelial growth factor receptors (VEGFRs), platelet-derived growth factor receptors (PDGFRs) and TAM (Tyro3, Axl and Mer) receptors [16-26]. Under physiological conditions, Axl is predominantly expressed in liver endothelial cells and mostly involved in platelet aggregation and vessel integrity. However, Axl is strongly expressed in malignant hepatocytes of about $40 \%$ of HCC patients showing progression towards metastasis $[27,28]$.

\section{Biology of Gas6/Axl in the Liver}

\subsection{Receptor and Ligands}

Together with Tyro3 and Mer, Axl belongs to the TAM receptor family of RTKs, which represents single-pass transmembrane proteins with tyrosine kinase activity. The TAM receptors share the conserved $\mathrm{KW}(\mathrm{I} / \mathrm{L}) \mathrm{A}(\mathrm{I} / \mathrm{L}) \mathrm{ES}$ sequence within the intracellular kinase domain which is unique for this family [29]. The ectodomain of Axl contains conserved tandem immunoglobulin-like domains, facilitating ligand binding, and fibronectin type III repeats (Figure 1A) [30,31]. The growth arrest specific gene (Gas)6 and Protein S (ProS) are vitamin K-dependent ligands of which Gas6 has the highest affinity for Axl, while ProS mainly binds to Tyro3 and Mer [32-35]. Both ligands share the C-terminal sex hormone-binding globulin region consisting of two laminin G-like domains and the $\mathrm{N}$-terminal lipid phosphatidylserine-binding Gla domain, which is required for potentiating the TAM receptor activation, and which plays an important role in phagocytosis [36,37]. TAM receptor activation requires vitamin K-dependent $\gamma$-carboxylation of Gas6 and ProS [38,39]. Gas6 binds to Axl in a 1:1 stoichiometry due to the binding of the two immunoglobulin-like domains of Axl to the laminin G-like domain of Gas6 (Figure 1B). This leads to homo-dimerization of Axl without direct contacts neither between the Axl nor between the Gas6 monomers [31,33]. Additionally, the tubby-like protein-1 is able to interact with TAM receptors, while tubby and Galectin-3 only activate Mer [40,41]. Ligand binding leads to trans-autophosphorylation of the intracellular domain (ICD) tyrosine residues, which provide docking sites for recruitment of intracellular signaling effectors [29]. Interestingly, overexpression of TAM RTKs could result in ligand-independent activation [29,30,42].

Axl-mediated proliferation and survival depend on the mitogen activated protein kinase (MAPK)/extracellular-signal regulated kinase (ERK) pathway and involve phosphoinositide 3-kinase (PI3K) and c-Jun-N-terminal kinase (JNK) activation [43,44]. Additionally, Ras, Twist and nuclear factor $\kappa$-light-chain-enhancer of activated B cells (NF- $\mathrm{kB}$ ) are downstream targets of Axl $[29,45,46]$. Yet, the Axl/PI3K/Akt and the Mer/PI3K/Akt pathways differ, since NF-KB is upregulated upon Axl activation, while Mer signaling downregulates NF- $\mathrm{kB}[47,48]$. Moreover, Axl is targeted by YAP1 and a mediator of YAP-dependent oncogenic signaling via ERK1/2 [49]. Furthermore, microenvironmental factors such as hypoxia activate Axl signaling in order to drive angiogenesis [50]. The hypoxia-inducible factor (HIF)- $1 \alpha$ and HIF- $2 \alpha$ bind to the hypoxia-response element in the Axl proximal promotor leading to transcriptional activation of Axl in HCC [51]. Another upstream regulator of $A x l$ is RAB10, which is associated with increased tumor size and advanced tumor staging in HCC patients [52]. 
A

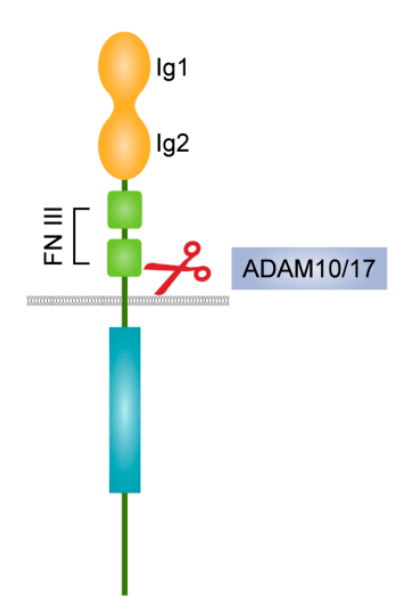

B

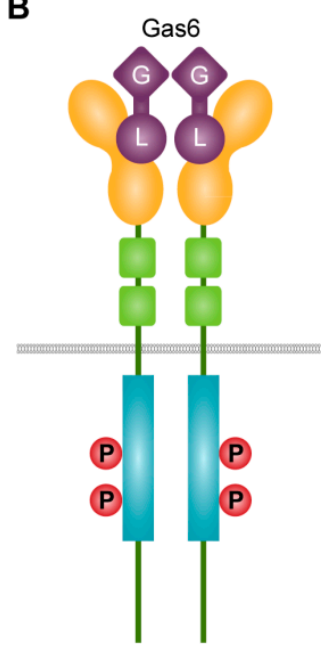

Figure 1. Structure and activation of Axl receptor. (A) The ectodomain of Axl consists of the N-terminal immunoglobulin-like Ig (Ig1, Ig2) and two fibronectin (FN) type III domains. ADAM10 and ADAM17 can cleave the ectodomain between valine 438 and tryptophan 452 (V438-W452) close to the transmembrane region. Red scissors indicate proteolytic cleavage. (B) Gas6/Axl homo-dimerizes in a 1:1 stoichiometry resulting in the tyrosine phosphorylation of ICDs. Gas6 binds to the Ig domains of Axl by the carboxy-terminal laminin G-like domain (L). The amino-terminal Gla domain of Gas6 (G) binds to the lipid phosphatidylserine.

Axl was originally found as a transforming gene in leukemia cells and has the ability to transform fibroblasts and myeloid cells through overexpression [53-55]. Axl is cleaved by a disintegrin and metalloproteinase (ADAM)10 and ADAM17 in a protein kinase $\mathrm{C}$ (PKC)-dependent fashion causing the release of soluble Axl (sAxl) which maintains the ability to interact with Gas6 [54,56,57]. Thus, the release of sAxl and its involvement in a negative feedback loop by Gas6 binding together with the $\gamma$-secretase-mediated release of a soluble Axl ICD suggests bidirectional signaling as shown for ErbB4 [58]. Since sAxl is able to bind Gas6 and therefore capable of depleting the ligand, it is considered to be a critical determinant in affecting autocrine or paracrine Axl signaling [57]. In addition to the ligand depletion by sAxl, the ICD of Axl could remain active supporting the idea of Gas6-independent signaling. In contrast, it has also been hypothesized that ectodomain shedding of Axl is a mechanism of dampening the signal cascade [59].

\subsection{Dichotomic Role of Axl in Cancer}

Dysregulation of Axl signaling causes inflammation, autoimmune disease and cancer [33]. Moreover, endogenous or exogenous overexpression of Axl alone can be sufficient to induce oncogenesis, emphasizing the transforming activity of Axl $[33,55]$. In the context of cancer, TAM RTKs and particularly Gas6/Axl signaling contribute to survival of tumor cells in response to apoptotic stimuli $[33,60]$. The Axl ligand Gas6 is secreted by tumor cells, the vasculature, tumor-infiltrating leukocytes and bone marrow progenitor cells in the tumor microenvironment (TME) $[27,61]$. Tumor-associated macrophages are stimulated to increase their Gas6 expression in the TME in comparison to resident tissue macrophages, which implicates a positive feedback loop in Gas6/Axl signaling [61]. In HCC, the Gas6/Axl pathway has been identified to promote tumor invasion by activating Slug [62]. Increased activation of Axl signaling mediates invasion and metastasis in various cancers, such as breast, lung, prostate and pancreatic cancer [63-67]. In line, Axl was identified as a crucial regulator of epithelial to mesenchymal transition (EMT) and chemoresistance (Figure 2) $[68,69]$. In HCC, malignant hepatocytes undergo EMT due to the cooperation of TGF- $\beta$ with Axl signaling, which leads to invasion of HCC cells [28]. The interaction of Gas6/Axl with 14-3-3 $\zeta$ activates JNK which subsequently switches TGF- $\beta$ towards tumor-progressive functions by 
aberrant phosphorylation of the Smad3 linker region and increased transcription of pro-metastatic genes. Additionally, Axl regulates angiogenesis in tumors, which is indicated by impaired endothelial tube formation upon inhibition of Axl signaling [70,71].

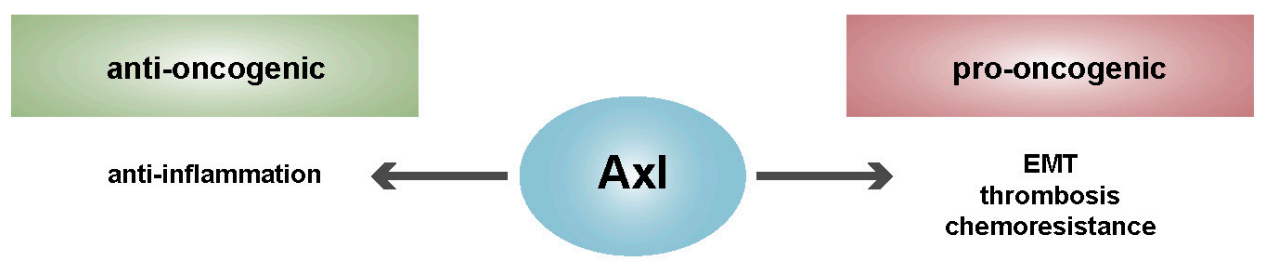

Figure 2. Dichotomy of Axl by anti- and pro-oncogenic actions. Axl prevents chronic inflammation while causing changes in epithelial cell plasticity, aggregation of platelets and escape from chemosensitivity. EMT, epithelial to mesenchymal transition.

TAM RTK signaling leads to metastasis as Axl and Mer inhibit the anti-tumor response of natural killer (NK) cells which are consequently disabled to kill disseminating cancer cells [72]. Beyond that, Gas6/ Axl signaling activates hepatic stellate cells (HSCs) to transit into myofibroblasts which results in fibrosis [73]. Additionally, Gas6/Mer signaling is suggested to be involved in liver fibrogenesis [74]. As described, liver fibrosis predisposes patients for HCC, which indicates that Gas6/Axl represents an oncogenic driver. Notably, Gas6/Axl is activated on aggregating platelets in the presence of phosphatidylserine, which allows stabilization of clot formation under physiological conditions [33,75]. After activation of PI3K/Akt, the cytoplasmic tail of $\beta 3$ integrin is phosphorylated leading to outside-in signaling [76]. This mediates a change in platelet shape, clot retraction and thrombus stabilization [75]. In this line, thrombosis is prevented in Gas6 knock-out (KO) mice due to impaired platelet aggregation [77]. Moreover, we hypothesize that TAM signaling might be involved in cancer-associated thrombosis since platelets in general are able to protect tumor cells in the circulation in order to facilitate metastatic colonization at distant sites [78]. Paracrine signaling of platelets suppresses the NK cell mediated lysis, which promotes tumor cell survival $[79,80]$. Thus, cancer patients are at high risk of developing deep vein thrombosis and pulmonary embolisms due to elevated expression and activity of Axl [81].

Axl is involved in chemoresistance since it is overexpressed in, for example, imatinib resistant tumor cells [82]. Inhibition of Axl by miRNA-34a-5p decreases chemoresistance of HCC cells to cisplatin [83], which was comparably observed in breast cancer [84]. In acute myeloid leukemia, increased Axl expression is associated with resistance against the chemotherapeutics doxorubicin, VP16 and cisplatin, as well as to FLT3 inhibitors $[85,86]$. Axl can also heterodimerize, for instance, with EGFR or ErbB2, which leads to activation of alternative signaling routes, also called bypass signaling, and diversification of downstream signaling facilitating chemoresistance [69,87-89]. On the one hand, inhibition of MAPK signaling (MAPKi) results in increased transcription of multiple RTKs via bypass signaling [90]. On the other hand, MAPKi leads to reduced ectodomain shedding as shown for Axl. Increased Axl expression further supports bypass signaling by increased JNK phosphorylation. Therefore, ectodomain shedding of Axl is a feedback mechanism that mediates the compensatory bypass signaling of JNK after MAPKi. Increased ectodomain shedding is able to inhibit this exit route by blocking bypass signaling and, thus, to antagonize TAM-mediated mechanisms of chemoresistance [90].

Contrary to oncogenic traits, TAM RTKs are important in the process of phagocytosis and suppression of the inflammatory cytokine response [33,91]. In particular, the clearance of apoptotic cells is TAM-dependent and plays a major role in the resolution of inflammation. Therefore, one of the physiological functions of the TAM family is to provide an inhibitory feedback mechanism, which promotes tissue repair [92,93]. In particular, Axl and Mer may play a major role in the anti-inflammatory process since they prevent and terminate innate immune-mediated inflammation [94]. The loss of all three TAM receptors results in autoimmunity, hyper-inflammation, hyperproliferation of lymphocytes 
and hepatitis $[95,96]$. In order to facilitate a proper immune response, Toll-like receptors (TLRs) regulate TAM signaling upstream to prevent chronic activation of antigen-presenting cells [35]. Activation of TLRs releases pro-inflammatory cytokines resulting in activation of type I interferon (IFN) receptors (IFNAR). IFNAR signaling through Janus kinase/signal transducers and activators of transcription (JAK/STAT) induces expression of the TAM RTKs, which then shut down the immune response via SOCS1, SOCS3, NF- $\mathrm{KB}$ inhibition and repression of the IFN regulatory factor $3[94,97]$. Inflammatory cytokines such as IL- $1 \beta$, IL- 6 , tumor necrosis factor (TNF)- $\alpha$, IFN- $\alpha$ and $-\beta$ are upregulated in the liver of TAM triple KO mice [96]. This TAM-induced feedback mechanism facilitates effective acute inflammation while preventing chronic disease. Since chronic inflammation is considered to be a major driver of tumorigenesis, TAM signaling acts tumor-suppressive due to its anti-inflammatory role (Figure 2) [35,98]. Furthermore, Gas6/Axl is suggested to positively regulate the expression of the tumor suppressor LIGHT (lymphotoxin-related inducible ligand that competes for glycoprotein D binding to herpesvirus entry mediator (HVEM) on T cells mediating an anti-oncogenic trait) which induces robust anti-tumor immunity [99]. Although tumor-associated macrophages are suggested to secrete Gas6 in the TME [100], the role of Gas6/Axl for the infiltration of macrophages remains an open issue. There might be a continuum of classically activated macrophages promoting acute inflammation (M1) and alternatively activated macrophages suppressing inflammation while promoting tissue repair and tumor progression (M2), leading to opposing phenotypes.

\subsection{Role of Gas6/Axl under Healthy and Pathological Conditions in the Liver}

Axl causes resistance to TGF- $\beta$ induced growth inhibition and decreases the susceptibility to TGF- $\beta$-induced apoptosis in HCC cells [28]. Furthermore, Axl elicits abilities for invasion and trans-endothelial migration of EMT-transformed HCC cells [26,28]. PI3K/Akt and PAK1 signaling is strongly reduced in Axl KO, as inhibition of these pathways leads to decreased HCC cell migration and invasion [26]. Axl KO results in reduced liver fibrosis in vivo following CCl4 treatment [73]. HSCs cultured from Axl KO mice exhibited decreased expression of markers for HSC activation, such as smooth muscle actin and collagen type 1, indicating reduced HSC activation.

Under healthy conditions, Gas6 is not secreted by HSCs, yet Kupffer cells contribute to Gas6 expression in the normal liver. Upon CCl4-induced liver injury, Gas6 secretion is stimulated in HSCs and in infiltrating macrophages [101]. Gas6 plays an important role in steatohepatitis and progression to liver fibrosis as Gas6 KO mice show a decreased disease burden. Furthermore, hepatic inflammation is reduced by limited infiltration of F4/80-positive macrophages and by decreased expression levels of IL-1 $\beta$, TNF- $\alpha$, monocyte chemotactic protein (MCP)- 1 and lymphotoxin- $\beta$ in Gas6-deficient mice. Attenuated myofibroblast activation and fibrogenesis together with lower TGF- $\beta$ and collagen type 1 expression is detected in Gas6-deficient mice subjected to a choline-deficient, ethionine-supplemented diet. In both models, Gas6 deficiency limits macrophage recruitment leading to a decreased amount of inflammatory cytokines in the liver [102]. Furthermore, Gas6 deficiency leads to delayed and limited liver regeneration in the CCl4-injured liver. The levels of MCP-1 secreted by activated Kupffer cells are reduced in Gas6 KO mice along with decreased IL-6, TNF- $\alpha$ and CD14 levels. These findings are consistent with defective Kupffer cell activation resulting in delayed and limited liver repair [103].

Gas6 is further involved in hepatic graft versus host disease (GVHD) since apoptosis of liver cells in portal spaces is significantly lower in Gas6 KO mice. This indicates that Gas6 deficiency reduces liver GVHD in recipients of allogenic bone marrow transplantation [104]. In a murine model of partial hepatic ischemia/reperfusion (I/R) injury, Gas6 is required for resolving partial I/R due to increased cell survival in the hepatic parenchyma. Furthermore, the levels of inflammatory mediators such as TNF- $\alpha$ and IL-1 $\beta$ are significantly elevated in the Gas6-deficient mice exposed to I/R [105].

In HCC, EMT-transformed hepatocytes rather than differentiated hepatocytes upregulate the expression of Axl and secrete Gas6, suggesting autocrine regulation of Gas6/Axl signaling (Figure 3) [28]. In the background of fibrosis, sinusoidal endothelial cells, activated HSCs and Axl-positive- myofibroblasts, as well as Kupffer cells, release Gas6 into the TME of HCC, causing a 
Gas6-enriched HCC stroma. These data suggest that Axl signaling drives HCC progression in the presence of large amounts of bioactive Gas6.

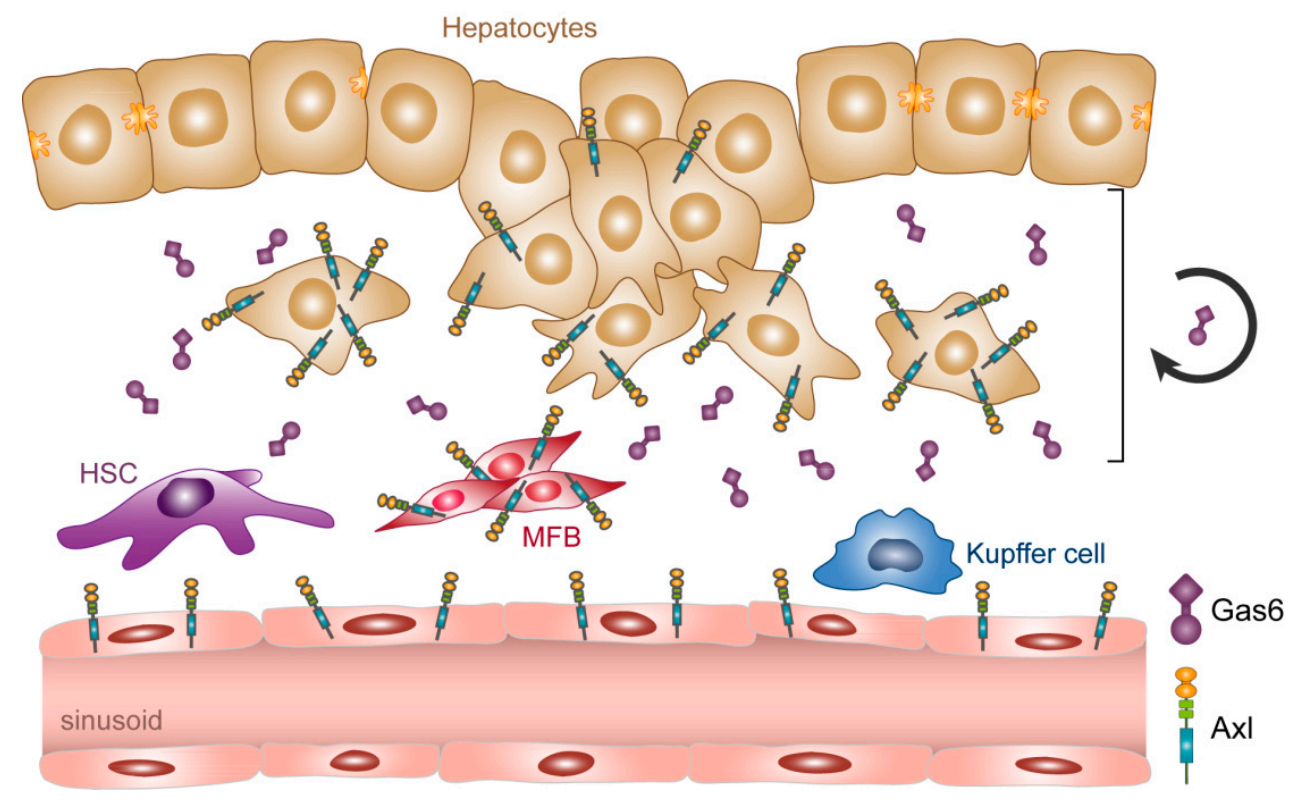

Figure 3. Expression of Gas6 and Axl in hepatocellular carcinoma (HCC). Malignant hepatocytes undergoing de-differentiation by EMT as well as HSCs trans-differentiating to MFBs upregulate Axl expression. EMT-transformed hepatocytes secrete Gas6 causing autocrine Gas6/Axl signaling. Activated HSCs/MFBs and Kupffer cells release Gas6 into the tumor microenvironment (TME). Circled arrow indicates autocrine Gas6/Axl signaling. HSC, hepatic stellate cell; MFB, myofibroblast.

\section{Cell Communication Regulated by Ectodomain Shedding}

Proteolytic cleavage of extracellular domains of transmembrane proteins is mainly performed by sheddases. This process referred to as ectodomain shedding is a posttranslational mechanism critically required for generating and regulating the active form of multiple growth factors, membrane-bound precursor ligands, adhesion molecules, cell surface receptors and ligand-independent signaling. All these functions of shedding facilitate signaling on host and neighboring cells [106,107]. Its regulatory function essentially affects cell-cell communication in development and tissue homeostasis, which is underlined by the observation that, e.g., deletion of ADAM17, one of the most prominent sheddases, is embryonic lethal [108]. Proteolytic cleavage of transmembrane proteins by sheddases such as ADAMs and matrix metalloproteases (MMPs) is induced by certain stimuli involving phorbol esters, calcium ionophores and cytokines such as TNF- $\alpha$, IFN- $\gamma$, IL-2, VEGF or IL-1 $\beta$ [109-114]. The subsequent activation of signaling pathways such as MAPK-, $\mathrm{PI} 3 \mathrm{~K} / \mathrm{Akt} / \mathrm{mammalian}$ target of rapamycin-, PKC-, as well as calcium-dependent signaling pathways cause ectodomain shedding $[90,115]$.

Shedding of pro-TGF- $\alpha$ by ADAM17 drives tumorigenesis by the release of soluble TGF- $\alpha$ and activation of the epidermal growth factor receptor (EGFR) signaling [116,117]. ADAM17, also known as TNF- $\alpha$ converting enzyme (TACE), was initially found to be the protease cleaving TNF- $\alpha$. Over time, a large number of ADAM17 target molecules were identified, among them ligands for EGFR, L-selectin, CD44 and VEGFR. All EGFR ligands are synthesized as membrane-bound precursors, which require ectodomain shedding for releasing the active ligand [118]. For instance, the membrane-bound precursor pro-heparin-binding EGF-like growth factor (HB-EGF) is shedded by several ADAMs [119]. Both, soluble HB-EGF and pro-HB-EGF are biologically active. The precursor molecule is able to act on neighboring cells in a juxtacrine manner as it is membrane-anchored, whereas the soluble protein can diffuse to distant sites leading to EGFR activation. Additionally, the C-terminal fragment of HB-EGF is internalized after proteolytic cleavage and able to transcriptionally modulate target genes in the 
nucleus. In this way, HB-EGF signals bidirectionally as the soluble ectodomain of HB-EGF binds to and activates EGFR, while the soluble ICD acts on transcriptional repressors causing activation of target genes $[120,121]$. Similarly, $\gamma$-secretase cleavage after ectodomain shedding occurs in ErbB4/HER4 leading to nuclear translocation of the soluble ICD [122]. In addition, the ErbB4-ICD keeps its tyrosine kinase function, while the ectodomain of ErbB4 is able to deplete the ligand causing a negative feedback loop [123]. Signaling activities of both ErbB4 cleavage products demonstrate bidirectional signaling as described for HB-EGF.

In line, the RTK Axl undergoes a $\gamma$-secretase-dependent cleavage after ectodomain shedding generating a soluble ICD [58]. A comparable mechanism to ErbB4 could be involved in Axl signaling since sAxl as well as Axl-ICD show biological activity resulting in ligand depletion by sAxl and target gene activation by Axl-ICD [57,124]. Further studies need to clarify whether Axl-ICD is able to maintain its tyrosine kinase activity like ErbB4-ICD, which would provide more information on ligand-independent signaling of Axl. Yet, target gene activation is not the only outcome of $\gamma$-secretase cleavage, as the soluble ICD can also be rapidly degraded, which is shown for Met and Tie1 [125,126]. Degradation of ICDs is an antagonistic mechanism to ligand-independent signaling. Therefore, $\gamma$-secretase cleavage of Axl can either lead to targeted degradation or to nuclear translocation of Axl-ICD, resulting in the cease of Axl signaling or activation of target genes.

Of note, the extracellular domain of ErbB2 is shedded by ADAMs and MMPs upon receptor activation. Notably, the resulting serum-detectable soluble fragment is able to reflect the activity state of the receptor since the ICD of ErbB2 is shown to be constitutively active [127,128]. An engineered deletion of the extracellular domain of ErbB2 increases the oncogenic potential through increased kinase activity due to ligand-independent signaling [129]. In this context, it remains an open issue whether ErbB2-like ligand-independent signaling is relevant for Axl functions.

\section{Axl Receptor Shedding: Gas6-Dependent Signaling versus Signal Dampening}

A previous study by Ekman et al. showed that Gas6 is bound to sAxl in human serum and plasma by an excess of sAxl [57]. The authors concluded that free Gas6 is captured by sAxl which suggests that sAxl downregulates Axl signaling by ligand depletion [57]. In consequence, HCC progression should be subsequently attenuated by diminished Gas6/Axl signaling. However, serum Gas6 levels are increased in patients with advanced fibrosis and cirrhosis as well as in HCC patients, suggesting that excess Gas6 is able to overcome the feedback inhibition of sAxl $[73,130]$, albeit, these data have to be confirmed in larger patient cohorts. In HCC, there is not only a positive correlation of serum Gas6 and sAxl levels with increased tumor staging, but there might be even an excess of Gas6 levels compared to sAxl [131]. Additionally, there is also increased expression of ADAM10 in HCC which is associated with tumor progression [132,133]. Increased ADAM10 expression might be involved in mediating increased Axl ectodomain shedding. As Gas6 is secreted by various liver cell types in the TME (Figure 3), abundant levels of free Gas6 might be available to bind cognate Axl receptors and to activate Axl signaling for cancer progression [61]. In line, Axl expression is upregulated in HCC and increased sAxl levels were found in patients with liver cirrhosis as well as very early to late stages of HCC [134,135].

In this scenario, it is also conceivable that Axl transduces an anti-oncogenic signal, which is dampened by sAxl leading to an oncogenic phenotype (Figure 4A). Yet, Gas6/Axl signaling induces the expression of pro-metastatic genes, such as SNAI1, MMP9 and TGF- $\beta 1$ in HCC, which are crucially involved in cell invasion and trans-endothelial migration of EMT-transformed hepatocytes [12,28]. Moreover, high Axl expression as well as high sAxl levels independently correlate with poor HCC patient survival, indicating that Gas6/Axl expression associates with a tumor-promoting rather than a tumor-suppressive signaling $[28,134]$. Consequently, these findings are contradictory to the hypothesis that ectodomain shedding of Axl leads to signal dampening. If sAxl is able to inhibit Gas6/Axl signaling, the oncogenic function should be blocked or at least attenuated. In this case, higher sAxl concentrations would implicate decreased disease progression and prolonged survival of HCC patients, 
which is not conclusive with recent data $[134,135]$. Since cancer patients with increased Axl expression show disease progression and advanced tumor staging resulting in rather metastatic phenotypes [27], the hypothesis is supported that Gas6 levels are in excess compared to sAxl and free Gas6 is available to activate non-shedded Axl receptor for amplifying Gas6-dependent Axl signaling in liver fibrosis and HCC (Figure 4B, right panel).

A

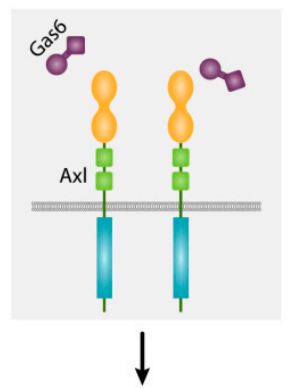

Signal dampening

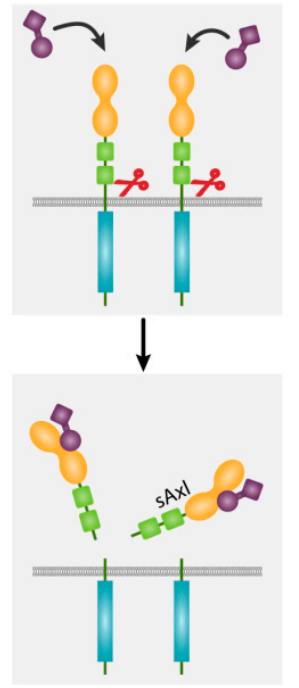

B
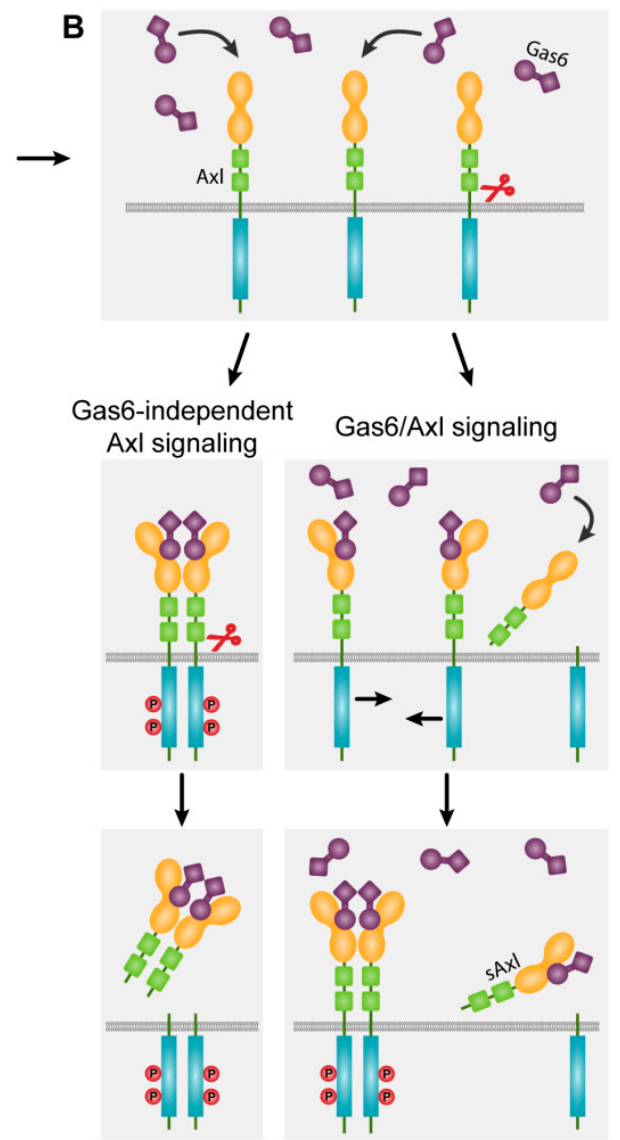

Figure 4. Axl signaling in liver fibrosis and HCC after ectodomain shedding. (A) Dampening of Gas6/Axl signaling. The monomeric Axl receptor is cleaved by proteases resulting in sAxl monomers that bind to and trap free Gas6. (B) Gas6-independent and Gas6-dependent Axl signaling. Middle left and lower panel: proteases cleave Gas6/Axl tetramers releasing sAxl dimers. Signaling of Axl receptor lacking the extracellular domain is questionable. Middle right and lower panel: In the presence of Gas6/sAxl complexes, abundant free Gas6 binds to Axl allowing homo-dimerization of receptors and activation of Axl signaling. Red scissors indicate proteolytic cleavage.

Recent findings support the idea of Gas6-dependent Axl signaling in liver fibrosis which has been revealed by Gas6 KO and Axl KO studies, showing reduced fibrogenesis [73,102]. In addition, latest studies show that sAxl levels are increased in advanced fibrosis/cirrhosis [73,135]. Notably, if increased sAxl levels deplete Gas6, Gas6 deficiency will not affect the development and progression of fibrosis. Since sAxl levels are increased in fibrosis, whereas either Gas6 or Axl deletion reduces fibrosis, we conclude that Gas6/Axl signaling is pro-fibrotic and that Gas6 levels exceed those of sAxl. Regarding the hypothesis of signal dampening, excess of sAxl should decrease fibrogenesis through capturing free Gas6, resulting in a phenotype comparable to the one of chemically challenged Gas6 KO mice [102]. In conclusion, observations from studies of Gas6 KO mice are in accordance with recent findings in patients and underline Gas6-dependent Axl signaling in liver fibrosis. Yet, solid evidence for the oncogenic Gas6-dependent Axl signaling in HCC requires further studies in HCC 
patients by determining levels of sAxl and free Gas6 as well as those levels of Gas6/sAxl complexes in patient blood.

If the Gas6 levels exceed the sAxl values, it will indicate that Gas6 overcomes the inhibitory feedback mechanism. This scenario suggests that there might be a switch predisposing fibrosis, cirrhosis or HCC development, where the inhibitory Axl shedding mechanism is circumvented. In the case that serum Gas6 is lower than sAxl, the Gas6/Axl signaling would be dampened, which would rather lead to the abrogation of an anti-fibrotic or anti-oncogenic signal driving fibrosis or HCC. We propose that cleavage of Axl does not contribute to the development or progression of liver fibrosis/cirrhosis and HCC due to the presence of abundant non-shedded Axl receptors overcoming the loss of proteolytically cleaved Axl. Available free Gas6 is then able to bind increasingly expressed Axl receptor and stimulate Gas6/ Axl signaling driving HCC progression (Figure 4B, right panel).

The Gas6-independent signaling hypothesis implicates that proteases are recruited to cleave the Axl ectodomain after Gas6-mediated Axl activation (Figure 4B, left panel). In this scenario, the ICD could remain active and could be still able to phosphorylate effector molecules. As a result, high Axl receptor expression would lead to increased Gas6-independent signaling, promote tumor growth as well as EMT and metastasis. However, it is an open question whether ectodomain shedding occurs after Axl homo-dimerization and ICD activation. Interestingly, the mechanism of shedding prior to receptor activation and ligand-independent signaling has been reported for ErbB2 [128].

\section{Theranostics: Diagnostic and Therapeutic Potential of Gas6/Axl}

Patients with early diagnosed HCC achieve a five-year survival rate of $60 \%$ after liver resection and a five-year survival rate of $67 \%$ post transplantation [136]. Unfortunately, the majority of HCC patients is diagnosed at advanced stages, resulting in a survival median of less than one year [137]. The question is whether the analysis of Gas6/sAxl levels in patients' blood can be used to diagnose advanced fibrosis/cirrhosis as well as HCC. Interestingly, recent large-scale multicenter studies demonstrated that sera of all HCC patients, including very early and early HCC, show elevated sAxl levels in the presence as well as absence of cirrhosis $[134,135]$. Receiver operating characteristic curve analysis of sAxl indicated an increased sensitivity and specificity to detect cirrhosis and HCC superior to $\alpha$-fetoprotein (AFP), which is used in HCC diagnostics. In addition, the combination of sAxl with AFP further increases the diagnostic accuracy in very early to late HCC patients [134]. As no false positive sAxl signals could be detected in, e.g., chronic HBV or HCV infection or NAFLD/NASH patients or secondary liver malignancies from colorectal cancer, sAxl is the most promising novel serum biomarker for the accurate detection of HCC. Yet, serum sAxl levels are also increased in chronic degenerative diseases of other organs such as the heart which could reduce the diagnostic specificity of sAxl [138].

With respect to the therapeutic intervention, the Gas6/Axl signaling pathway represents a promising target in HCC. For instance, an engineered Axl decoy receptor that was shown to trap Gas6 with higher affinity than the wildtype Axl receptor could lead to effective sequestration of Gas6 and thus, to a decrease of Axl signaling [139]. Targeting Axl signaling with this Axl decoy receptor has shown promising results in models of ovarian and breast cancer metastasis. In contrast to the anti-Axl tyrosine kinase inhibitors (TKis) foretinib and BGB324, the Axl decoy receptor specifically inhibits Axl signaling without affecting Tyro3 or Mer activity. Despite comparable efficacies of Axl decoy receptor and TKis, foretinib caused side effects in $91 \%$ of patients in a phase II trial [140]. Nevertheless, it has not been clarified whether the Axl decoy receptor affects the immune system or if there are adverse effects on inflammation. In addition, the synergy of Axl and TGF- $\beta$ leading to neutrophil infiltration renders an alternative target for HCC therapy involving the TME [141]. Interestingly, the secretion of the neutrophil attractant CXCL5 depends on the molecular collaboration of Gas6/Axl and TGF- $\beta$-signaling in TGF- $\beta$-positive HCC patients [141]. CXCL5 causes chemotaxis and activation of neutrophils, which leads to intra-tumoral macrophage and $\mathrm{T}$ cell infiltration resulting in enhanced 
HCC progression [142]. CXCL5 expression could be directly targeted by pharmacological intervention in order to avoid harmful effects of either anti-TGF- $\beta$ or anti-Axl therapies.

\section{Conclusions}

Ectodomain shedding is a posttranslational mechanism that either acts through the released extracellular domain, the soluble ICD, or bidirectionally through both. Proteolytic cleavage of Axl has not been sufficiently studied yet, which raises multiple questions. In particular, the role of Gas6/Axl signaling in liver fibrosis and HCC requires further elucidation in order to test several hypotheses. As suggested by Ekman et al., ectodomain shedding of Axl could serve as an inhibitory feedback mechanism to shut down the Gas6/Axl signaling route [57]. In this hypothesis, Gas6/Axl signaling is dampened by sAxl. As shown for ErbB4, the soluble extracellular domain could be able to neutralize the ligand, which would support Ekman et al.'s hypothesis. Nevertheless, $\gamma$-secretase activity after ectodomain cleavage could still mediate signaling to the nucleus which would result in bidirectional signaling $[57,124]$. An alternative hypothesis suggests that abundant free Gas6 in the TME could overcome this inhibitory feedback mechanism for promoting fibrosis and HCC. Additionally, shedding of activated Axl receptors could lead to Gas6-independent signaling driving disease progression.

In conclusion, the emerging role of Axl in theranostics of HCC is reflected by the promising results of sAxl as an innovative diagnostic biomarker. Beyond, sAxl levels are able to stratify patients according to liver disease stages indicating that $\mathrm{Axl}$ as well as sAxl are valuable tools for precision medicine. In addition, CXCL5 might be a promising therapeutic target in Axl/TGF- $\beta$-positive patients. To further elucidate the role and mechanism of Gas6/Axl signaling, the Gas6 as well as the Gas6/sAxl complex levels have to be analyzed in blood samples of fibrosis and HCC patients. Examining the combination of Gas6 and Axl will clarify the role and mechanism of ectodomain shedding and might strengthen diagnostic and therapeutic strategies to combat liver fibrosis and HCC.

Author Contributions: Conceptualization, E.H. and W.M.; writing-original draft preparation, E.H. and M.B.; writing-review and final editing, W.M.; artwork, E.H., M.B. and W.M.; funding acquisition, W.M.

Funding: This work was supported by the Austrian Science Fund, FWF, P25356.

Acknowledgments: The authors thank Heidemarie Huber for artwork and Eva Řezníčková for critical reading of the manuscript. We apologize to those authors of publications whose experimental work has only been cited indirectly because of space limitations.

Conflicts of Interest: The authors declare no conflict of interest.

\section{Abbreviations}

$\begin{array}{ll}\text { ADAM } & \text { a disintegrin and metalloproteinase } \\ \text { AFP } & \alpha \text {-fetoprotein } \\ \text { BCLC } & \text { Barcelona Clinic Liver Cancer } \\ \text { EGFR } & \text { epidermal growth factor receptor } \\ \text { EMT } & \text { epithelial to mesenchymal transition } \\ \text { ERK } & \text { extracellular-signal regulated kinase } \\ \text { FLT3 } & \text { FMS-like tyrosine kinase } \\ \text { Gas6 } & \text { growth arrest specific gene 6 } \\ \text { GVHD } & \text { graft versus host disease } \\ \text { HB-EGF } & \text { heparin-binding EGF-like growth factor } \\ \text { HBV } & \text { hepatitis B virus } \\ \text { HCC } & \text { hepatocellular carcinoma } \\ \text { HCV } & \text { hepatitis C virus } \\ \text { HER } & \text { human epidermal growth factor receptor } \\ \text { HIF } & \text { hypoxia- inducible factor } \\ \text { HSC } & \text { hepatic stellate cell } \\ \text { I/R } & \text { ischemia/reperfusion } \\ \text { ICD } & \text { intracellular domain }\end{array}$




\begin{tabular}{|c|c|}
\hline IFN & interferon \\
\hline IFNAR & interferon $\alpha / \beta$ receptor \\
\hline IL & interleukin \\
\hline JAK/STAT & Janus kinase/signal transducers and activators of transcription \\
\hline JNK & c-Jun-N-terminal kinase \\
\hline $\mathrm{KO}$ & knock-out \\
\hline MAPK & mitogen activated protein kinase \\
\hline MAPKi & inhibition of the MAPK pathway \\
\hline MCP & monocyte chemotactic protein \\
\hline MMP & matrix metalloprotease \\
\hline NAFLD & non-alcoholic fatty liver disease \\
\hline NASH & non-alcoholic steatohepatitis \\
\hline $\mathrm{NF}-\kappa \mathrm{B}$ & nuclear factor $\mathrm{k}$-light-chain-enhancer of activated B cells \\
\hline NK & natural killer \\
\hline PDGFR & platelet-derived growth factor receptor \\
\hline PI3K & phosphoinositide 3-kinase \\
\hline PKC & protein kinase $\mathrm{C}$ \\
\hline ProS & Protein S \\
\hline RTK & receptor tyrosine kinase \\
\hline sAxl & soluble Axl \\
\hline sIL-6R & soluble interleukin-6 receptor \\
\hline SOCS & suppressors of cytokine signaling \\
\hline TAM & Tyro3, Axl, Mer \\
\hline TGF & transforming growth factor \\
\hline TKi & tyrosine kinase inhibitors \\
\hline TLR & Toll-like receptor \\
\hline TME & tumor microenvironment \\
\hline TNF & tumor necrosis factor \\
\hline VEGFR & vascular endothelial growth factor receptor \\
\hline YAP & Yes-associated protein \\
\hline
\end{tabular}

\section{References}

1. Forner, A.; Llovet, J.M.; Bruix, J. Hepatocellular carcinoma. Lancet 2012, 379, 1245-1255. [CrossRef]

2. Jemal, A.; Bray, F.; Center, M.M.; Ferlay, J.; Ward, E.; Forman, D. Global cancer statistics. CA Cancer J. Clin. 2011, 61, 69-90. [CrossRef] [PubMed]

3. El-Serag, H.B. Hepatocellular carcinoma. N. Engl. J. Med. 2011, 365, 1118-1127. [CrossRef] [PubMed]

4. Bruix, J.; Sherman, M. Management of hepatocellular carcinoma: An update. Hepatology 2011, 53, 1020-1022. [CrossRef] [PubMed]

5. European Association for the Study of the Liver; European Organisation for Research and Treatment of Cancer. EASL-EORTC clinical practice guidelines: Management of hepatocellular carcinoma. J. Hepatol. 2012, 56, 908-943. [CrossRef] [PubMed]

6. Rimassa, L.; Pressiani, T.; Personeni, N.; Santoro, A. Regorafenib for the treatment of unresectable hepatocellular carcinoma. Expert Rev. Anticancer Ther. 2017, 17, 567-576. [CrossRef] [PubMed]

7. Nault, J.C.; Zucman-Rossi, J. TERT promoter mutations in primary liver tumors. Clin. Res. Hepatol. Gastroenterol. 2016, 40, 9-14. [CrossRef] [PubMed]

8. Ding, X.X.; Zhu, Q.G.; Zhang, S.M.; Guan, L.; Li, T.; Zhang, L.; Wang, S.Y.; Ren, W.L.; Chen, X.M.; Zhao, J.; et al. Precision medicine for hepatocellular carcinoma: Driver mutations and targeted therapy. Oncotarget 2017, 8, 55715-55730. [CrossRef] [PubMed]

9. Li, M.; Zhao, H.; Zhang, X.; Wood, L.D.; Anders, R.A.; Choti, M.A.; Pawlik, T.M.; Daniel, H.D.; Kannangai, R.; Offerhaus, G.J.; et al. Inactivating mutations of the chromatin remodeling gene ARID2 in hepatocellular carcinoma. Nat. Genet. 2011, 43, 828-829. [CrossRef] [PubMed] 
10. Fujimoto, A.; Totoki, Y.; Abe, T.; Boroevich, K.A.; Hosoda, F.; Nguyen, H.H.; Aoki, M.; Hosono, N.; Kubo, M.; Miya, F.; et al. Whole-genome sequencing of liver cancers identifies etiological influences on mutation patterns and recurrent mutations in chromatin regulators. Nat. Genet. 2012, 44, 760-764. [CrossRef] [PubMed]

11. Cleary, S.P.; Jeck, W.R.; Zhao, X.; Chen, K.; Selitsky, S.R.; Savich, G.L.; Tan, T.X.; Wu, M.C.; Getz, G.; Lawrence, M.S.; et al. Identification of driver genes in hepatocellular carcinoma by exome sequencing. Hepatology 2013, 58, 1693-1702. [CrossRef] [PubMed]

12. Giannelli, G.; Koudelkova, P.; Dituri, F.; Mikulits, W. Role of epithelial to mesenchymal transition in hepatocellular carcinoma. J. Hepatol. 2016, 65, 798-808. [CrossRef] [PubMed]

13. Giannelli, G.; Villa, E.; Lahn, M. Transforming growth factor- $\beta$ as a therapeutic target in hepatocellular carcinoma. Cancer Res. 2014, 74, 1890-1894. [CrossRef] [PubMed]

14. Farazi, P.A.; DePinho, R.A. Hepatocellular carcinoma pathogenesis: From genes to environment. Nat. Rev. Cancer 2006, 6, 674-687. [CrossRef] [PubMed]

15. Niu, Z.S.; Niu, X.J.; Wang, W.H. Genetic alterations in hepatocellular carcinoma: An update. World J. Gastroenterol. 2016, 22, 9069-9095. [CrossRef] [PubMed]

16. Tsou, A.P.; Wu, K.M.; Tsen, T.Y.; Chi, C.W.; Chiu, J.H.; Lui, W.Y.; Hu, C.P.; Chang, C.; Chou, C.K.; Tsai, S.F. Parallel hybridization analysis of multiple protein kinase genes: Identification of gene expression patterns characteristic of human hepatocellular carcinoma. Genomics 1998, 50, 331-340. [CrossRef]

17. Lanaya, H.; Natarajan, A.; Komposch, K.; Li, L.; Amberg, N.; Chen, L.; Wculek, S.K.; Hammer, M.; Zenz, R.; Peck-Radosavljevic, M.; et al. EGFR has a tumour-promoting role in liver macrophages during hepatocellular carcinoma formation. Nat. Cell Biol. 2014, 16, 972-977. [CrossRef] [PubMed]

18. Jiang, L.H.; Hao, Y.L.; Zhu, J.W. Expression and prognostic value of HER-2/neu, STAT3 and SOCS3 in hepatocellular carcinoma. Clin. Res. Hepatol. Gastroenterol. 2018. [CrossRef] [PubMed]

19. Gauglhofer, C.; Sagmeister, S.; Schrottmaier, W.; Fischer, C.; Rodgarkia-Dara, C.; Mohr, T.; Stattner, S.; Bichler, C.; Kandioler, D.; Wrba, F.; et al. Up-regulation of the fibroblast growth factor 8 subfamily in human hepatocellular carcinoma for cell survival and neoangiogenesis. Hepatology 2011, 53, 854-864. [CrossRef] [PubMed]

20. Rebouissou, S.; La Bella, T.; Rekik, S.; Imbeaud, S.; Calatayud, A.L.; Rohr-Udilova, N.; Martin, Y.; Couchy, G.; Bioulac-Sage, P.; Grasl-Kraupp, B.; et al. Proliferation markers are associated with MET expression in hepatocellular carcinoma and predict tivantinib sensitivity in vitro. Clin. Cancer Res. 2017, 23, 4364-4375. [CrossRef] [PubMed]

21. Garcia-Vilas, J.A.; Medina, M.A. Updates on the hepatocyte growth factor/c-Met axis in hepatocellular carcinoma and its therapeutic implications. World J. Gastroenterol. 2018, 24, 3695-3708. [CrossRef] [PubMed]

22. Chen, B.; Liu, J.; Wang, X.; Shen, Q.; Li, C.; Dai, C. Co-expression of PDGF-B and VEGFR-3 strongly correlates with poor prognosis in hepatocellular carcinoma patients after hepatectomy. Clin. Res. Hepatol. Gastroenterol. 2018, 42, 126-133. [CrossRef] [PubMed]

23. Li, T.; Zhu, Y.; Han, L.; Ren, W.; Liu, H.; Qin, C. VEGFR-1 activation-induced MMP-9-dependent invasion in hepatocellular carcinoma. Future Oncol. 2015, 11, 3143-3157. [CrossRef] [PubMed]

24. Yu, J.H.; Kim, J.M.; Kim, J.K.; Choi, S.J.; Lee, K.S.; Lee, J.W.; Chang, H.Y.; Lee, J.I. Platelet-derived growth factor receptor $\alpha$ in hepatocellular carcinoma is a prognostic marker independent of underlying liver cirrhosis. Oncotarget 2017, 8, 39534-39546. [CrossRef] [PubMed]

25. Duan, Y.; Wong, W.; Chua, S.C.; Wee, H.L.; Lim, S.G.; Chua, B.T.; Ho, H.K. Overexpression of Tyro3 and its implications on hepatocellular carcinoma progression. Int. J. Oncol. 2016, 48, 358-366. [CrossRef] [PubMed]

26. Xu, J.; Jia, L.; Ma, H.; Li, Y.; Ma, Z.; Zhao, Y. Axl gene knockdown inhibits the metastasis properties of hepatocellular carcinoma via PI3K/Akt-PAK1 signal pathway. Tumour Biol. 2014, 35, 3809-3817. [CrossRef] [PubMed]

27. Rankin, E.B.; Giaccia, A.J. The Receptor Tyrosine Kinase AXL in Cancer Progression. Cancers $2016,8$. [CrossRef] [PubMed]

28. Reichl, P.; Dengler, M.; van Zijl, F.; Huber, H.; Fuhrlinger, G.; Reichel, C.; Sieghart, W.; Peck-Radosavljevic, M.; Grubinger, M.; Mikulits, W. Axl activates autocrine transforming growth factor- $\beta$ signaling in hepatocellular carcinoma. Hepatology 2015, 61, 930-941. [CrossRef] [PubMed] 
29. Linger, R.M.; Keating, A.K.; Earp, H.S.; Graham, D.K. TAM receptor tyrosine kinases: Biologic functions, signaling, and potential therapeutic targeting in human cancer. Adv. Cancer Res. 2008, 100, 35-83. [CrossRef] [PubMed]

30. Heiring, C.; Dahlback, B.; Muller, Y.A. Ligand recognition and homophilic interactions in Tyro3: Structural insights into the Axl/Tyro3 receptor tyrosine kinase family. J. Biol. Chem. 2004, 279, 6952-6958. [CrossRef] [PubMed]

31. Sasaki, T.; Knyazev, P.G.; Clout, N.J.; Cheburkin, Y.; Gohring, W.; Ullrich, A.; Timpl, R.; Hohenester, E. Structural basis for Gas6-Axl signalling. EMBO J. 2006, 25, 80-87. [CrossRef] [PubMed]

32. Stitt, T.N.; Conn, G.; Gore, M.; Lai, C.; Bruno, J.; Radziejewski, C.; Mattsson, K.; Fisher, J.; Gies, D.R.; Jones, P.F.; et al. The anticoagulation factor protein $\mathrm{S}$ and its relative, Gas6, are ligands for the Tyro 3/Axl family of receptor tyrosine kinases. Cell 1995, 80, 661-670. [CrossRef]

33. Graham, D.K.; DeRyckere, D.; Davies, K.D.; Earp, H.S. The TAM family: Phosphatidylserine sensing receptor tyrosine kinases gone awry in cancer. Nat. Rev. Cancer 2014, 14, 769-785. [CrossRef] [PubMed]

34. Varnum, B.C.; Young, C.; Elliott, G.; Garcia, A.; Bartley, T.D.; Fridell, Y.W.; Hunt, R.W.; Trail, G.; Clogston, C.; Toso, R.J.; et al. Axl receptor tyrosine kinase stimulated by the vitamin K-dependent protein encoded by growth-arrest-specific gene 6. Nature 1995, 373, 623-626. [CrossRef] [PubMed]

35. Paolino, M.; Penninger, J.M. The role of TAM family receptors in immune cell function: Implications for cancer therapy. Cancers 2016, 8. [CrossRef] [PubMed]

36. Lew, E.D.; Oh, J.; Burrola, P.G.; Lax, I.; Zagorska, A.; Traves, P.G.; Schlessinger, J.; Lemke, G. Differential TAM receptor-ligand-phospholipid interactions delimit differential TAM bioactivities. Elife 2014, 3. [CrossRef] [PubMed]

37. Axelrod, H.; Pienta, K.J. Axl as a mediator of cellular growth and survival. Oncotarget 2014, 5, 8818-8852. [CrossRef] [PubMed]

38. Tsou, W.I.; Nguyen, K.Q.; Calarese, D.A.; Garforth, S.J.; Antes, A.L.; Smirnov, S.V.; Almo, S.C.; Birge, R.B.; Kotenko, S.V. Receptor tyrosine kinases, TYRO3, AXL, and MER, demonstrate distinct patterns and complex regulation of ligand-induced activation. J. Biol. Chem. 2014, 289, 25750-25763. [CrossRef] [PubMed]

39. Kirane, A.; Ludwig, K.F.; Sorrelle, N.; Haaland, G.; Sandal, T.; Ranaweera, R.; Toombs, J.E.; Wang, M.; Dineen, S.P.; Micklem, D.; et al. Warfarin blocks Gas6-mediated Axl activation required for pancreatic cancer epithelial plasticity and metastasis. Cancer Res. 2015, 75, 3699-3705. [CrossRef] [PubMed]

40. Caberoy, N.B.; Zhou, Y.; Li, W. Tubby and tubby-like protein 1 are new MerTK ligands for phagocytosis. EMBO J. 2010, 29, 3898-3910. [CrossRef] [PubMed]

41. Caberoy, N.B.; Alvarado, G.; Bigcas, J.L.; Li, W. Galectin-3 is a new MerTK-specific eat-me signal. J. Cell. Physiol. 2012, 227, 401-407. [CrossRef] [PubMed]

42. Burchert, A.; Attar, E.C.; McCloskey, P.; Fridell, Y.W.; Liu, E.T. Determinants for transformation induced by the Axl receptor tyrosine kinase. Oncogene 1998, 16, 3177-3187. [CrossRef] [PubMed]

43. Goruppi, S.; Ruaro, E.; Varnum, B.; Schneider, C. Requirement of phosphatidylinositol 3-kinase-dependent pathway and Src for Gas6-Axl mitogenic and survival activities in NIH 3 T3 fibroblasts. Mol. Cell. Biol. 1997, 17, 4442-4453. [CrossRef] [PubMed]

44. Goruppi, S.; Ruaro, E.; Varnum, B.; Schneider, C. Gas6-mediated survival in NIH3T3 cells activates stress signalling cascade and is independent of Ras. Oncogene 1999, 18, 4224-4236. [CrossRef] [PubMed]

45. Sharif, M.N.; Sosic, D.; Rothlin, C.V.; Kelly, E.; Lemke, G.; Olson, E.N.; Ivashkiv, L.B. Twist mediates suppression of inflammation by type I IFNs and Axl. J. Exp. Med. 2006, 203, 1891-1901. [CrossRef] [PubMed]

46. Sosic, D.; Richardson, J.A.; Yu, K.; Ornitz, D.M.; Olson, E.N. Twist regulates cytokine gene expression through a negative feedback loop that represses NF-кB activity. Cell 2003, 112, 169-180. [CrossRef]

47. Demarchi, F.; Verardo, R.; Varnum, B.; Brancolini, C.; Schneider, C. Gas6 anti-apoptotic signaling requires NF- $\mathrm{BB}$ activation. J. Biol. Chem. 2001, 276, 31738-31744. [CrossRef] [PubMed]

48. Sen, P.; Wallet, M.A.; Yi, Z.; Huang, Y.; Henderson, M.; Mathews, C.E.; Earp, H.S.; Matsushima, G.; Baldwin, A.S., Jr.; Tisch, R.M. Apoptotic cells induce Mer tyrosine kinase-dependent blockade of NF- $\mathrm{kB}$ activation in dendritic cells. Blood 2007, 109, 653-660. [CrossRef] [PubMed]

49. Xu, M.Z.; Chan, S.W.; Liu, A.M.; Wong, K.F.; Fan, S.T.; Chen, J.; Poon, R.T.; Zender, L.; Lowe, S.W.; Hong, W.; et al. AXL receptor kinase is a mediator of YAP-dependent oncogenic functions in hepatocellular carcinoma. Oncogene 2011, 30, 1229-1240. [CrossRef] [PubMed] 
50. Yttersian Sletta, K.; Tveitaras, M.K.; Lu, N.; Engelsen, A.S.T.; Reed, R.K.; Garmann-Johnsen, A.; Stuhr, L. Oxygen-dependent regulation of tumor growth and metastasis in human breast cancer xenografts. PLoS ONE 2017, 12, e0183254. [CrossRef] [PubMed]

51. Rankin, E.B.; Fuh, K.C.; Castellini, L.; Viswanathan, K.; Finger, E.C.; Diep, A.N.; LaGory, E.L.; Kariolis, M.S.; Chan, A.; Lindgren, D.; et al. Direct regulation of GAS6/AXL signaling by HIF promotes renal metastasis through SRC and MET. Proc. Natl. Acad. Sci. USA 2014, 111, 13373-13378. [CrossRef] [PubMed]

52. Wang, W.; Jia, W.D.; Hu, B.; Pan, Y.Y. RAB10 overexpression promotes tumor growth and indicates poor prognosis of hepatocellular carcinoma. Oncotarget 2017, 8, 26434-26447. [CrossRef] [PubMed]

53. McCloskey, P.; Pierce, J.; Koski, R.A.; Varnum, B.; Liu, E.T. Activation of the Axl receptor tyrosine kinase induces mitogenesis and transformation in 32D cells. Cell. Growth Differ. 1994, 5, 1105-1117. [PubMed]

54. O'Bryan, J.P.; Fridell, Y.W.; Koski, R.; Varnum, B.; Liu, E.T. The transforming receptor tyrosine kinase, Axl, is post-translationally regulated by proteolytic cleavage. J. Biol. Chem. 1995, 270, 551-557. [CrossRef] [PubMed]

55. O'Bryan, J.P.; Frye, R.A.; Cogswell, P.C.; Neubauer, A.; Kitch, B.; Prokop, C.; Espinosa, R., 3rd; Le Beau, M.M.; Earp, H.S.; Liu, E.T. Axl, a transforming gene isolated from primary human myeloid leukemia cells, encodes a novel receptor tyrosine kinase. Mol. Cell. Biol. 1991, 11, 5016-5031. [CrossRef] [PubMed]

56. Orme, J.J.; Du, Y.; Vanarsa, K.; Mayeux, J.; Li, L.; Mutwally, A.; Arriens, C.; Min, S.; Hutcheson, J.; Davis, L.S.; et al. Heightened cleavage of Axl receptor tyrosine kinase by ADAM metalloproteases may contribute to disease pathogenesis in SLE. Clin. Immunol. 2016, 169, 58-68. [CrossRef] [PubMed]

57. Ekman, C.; Stenhoff, J.; Dahlback, B. Gas6 is complexed to the soluble tyrosine kinase receptor Axl in human blood. J. Thromb. Haemost. 2010, 8, 838-844. [CrossRef] [PubMed]

58. Merilahti, J.A.M.; Ojala, V.K.; Knittle, A.M.; Pulliainen, A.T.; Elenius, K. Genome-wide screen of $\gamma$-secretase-mediated intramembrane cleavage of receptor tyrosine kinases. Mol. Biol. Cell 2017, 28, 3123-3131. [CrossRef] [PubMed]

59. Miller, M.A.; Sullivan, R.J.; Lauffenburger, D.A. Molecular Pathways: Receptor Ectodomain Shedding in Treatment, Resistance, and Monitoring of Cancer. Clin. Cancer Res. 2017, 23, 623-629. [CrossRef] [PubMed]

60. Ben-Batalla, I.; Schultze, A.; Wroblewski, M.; Erdmann, R.; Heuser, M.; Waizenegger, J.S.; Riecken, K.; Binder, M.; Schewe, D.; Sawall, S.; et al. Axl, a prognostic and therapeutic target in acute myeloid leukemia mediates paracrine crosstalk of leukemia cells with bone marrow stroma. Blood 2013, 122, 2443-2452. [CrossRef] [PubMed]

61. Loges, S.; Schmidt, T.; Tjwa, M.; van Geyte, K.; Lievens, D.; Lutgens, E.; Vanhoutte, D.; Borgel, D.; Plaisance, S.; Hoylaerts, M.; et al. Malignant cells fuel tumor growth by educating infiltrating leukocytes to produce the mitogen Gas6. Blood 2010, 115, 2264-2273. [CrossRef] [PubMed]

62. Lee, H.J.; Jeng, Y.M.; Chen, Y.L.; Chung, L.; Yuan, R.H. Gas6/Axl pathway promotes tumor invasion through the transcriptional activation of Slug in hepatocellular carcinoma. Carcinogenesis 2014, 35, 769-775. [CrossRef] [PubMed]

63. Holland, S.J.; Pan, A.; Franci, C.; Hu, Y.; Chang, B.; Li, W.; Duan, M.; Torneros, A.; Yu, J.; Heckrodt, T.J.; et al. R428, a selective small molecule inhibitor of Axl kinase, blocks tumor spread and prolongs survival in models of metastatic breast cancer. Cancer Res. 2010, 70, 1544-1554. [CrossRef] [PubMed]

64. Sainaghi, P.P.; Castello, L.; Bergamasco, L.; Galletti, M.; Bellosta, P.; Avanzi, G.C. Gas6 induces proliferation in prostate carcinoma cell lines expressing the Axl receptor. J. Cell. Physiol. 2005, 204, 36-44. [CrossRef] [PubMed]

65. Song, X.; Wang, H.; Logsdon, C.D.; Rashid, A.; Fleming, J.B.; Abbruzzese, J.L.; Gomez, H.F.; Evans, D.B. Overexpression of receptor tyrosine kinase Axl promotes tumor cell invasion and survival in pancreatic ductal adenocarcinoma. Cancer 2011, 117, 734-743. [CrossRef] [PubMed]

66. Shieh, Y.S.; Lai, C.Y.; Kao, Y.R.; Shiah, S.G.; Chu, Y.W.; Lee, H.S.; Wu, C.W. Expression of axl in lung adenocarcinoma and correlation with tumor progression. Neoplasia 2005, 7, 1058-1064. [PubMed]

67. Meric, F.; Lee, W.P.; Sahin, A.; Zhang, H.; Kung, H.J.; Hung, M.C. Expression profile of tyrosine kinases in breast cancer. Clin. Cancer Res. 2002, 8, 361-367. [PubMed]

68. Antony, J.; Huang, R.Y. AXL-driven EMT state as a targetable conduit in cancer. Cancer Res. 2017, 77, 3725-3732. [CrossRef] [PubMed]

69. Vouri, M.; Hafizi, S. TAM receptor tyrosine kinases in cancer drug resistance. Cancer Res. 2017, 77, $2775-2778$. [CrossRef] [PubMed] 
70. Ye, X.; Li, Y.; Stawicki, S.; Couto, S.; Eastham-Anderson, J.; Kallop, D.; Weimer, R.; Wu, Y.; Pei, L. An anti-Axl monoclonal antibody attenuates xenograft tumor growth and enhances the effect of multiple anticancer therapies. Oncogene 2010, 29, 5254-5264. [CrossRef] [PubMed]

71. Li, Y.; Ye, X.; Tan, C.; Hongo, J.A.; Zha, J.; Liu, J.; Kallop, D.; Ludlam, M.J.; Pei, L. Axl as a potential therapeutic target in cancer: Role of Axl in tumor growth, metastasis and angiogenesis. Oncogene 2009, 28, 3442-3455. [CrossRef] [PubMed]

72. Paolino, M.; Choidas, A.; Wallner, S.; Pranjic, B.; Uribesalgo, I.; Loeser, S.; Jamieson, A.M.; Langdon, W.Y.; Ikeda, F.; Fededa, J.P.; et al. The E3 ligase Cbl-b and TAM receptors regulate cancer metastasis via natural killer cells. Nature 2014, 507, 508-512. [CrossRef] [PubMed]

73. Barcena, C.; Stefanovic, M.; Tutusaus, A.; Joannas, L.; Menendez, A.; Garcia-Ruiz, C.; Sancho-Bru, P.; Mari, M.; Caballeria, J.; Rothlin, C.V.; et al. Gas6/Axl pathway is activated in chronic liver disease and its targeting reduces fibrosis via hepatic stellate cell inactivation. J. Hepatol. 2015, 63, 670-678. [CrossRef] [PubMed]

74. Petta, S.; Valenti, L.; Marra, F.; Grimaudo, S.; Tripodo, C.; Bugianesi, E.; Camma, C.; Cappon, A.; Di Marco, V.; Di Maira, G.; et al. MERTK rs4374383 polymorphism affects the severity of fibrosis in non-alcoholic fatty liver disease. J. Hepatol. 2016, 64, 682-690. [CrossRef] [PubMed]

75. Law, L.A.; Graham, D.K.; di Paola, J.; Branchford, B.R. GAS6/TAM pathway signaling in hemostasis and thrombosis. Front. Med. 2018, 5, 137. [CrossRef] [PubMed]

76. Shattil, S.J.; Newman, P.J. Integrins: Dynamic scaffolds for adhesion and signaling in platelets. Blood 2004, 104, 1606-1615. [CrossRef] [PubMed]

77. Angelillo-Scherrer, A.; de Frutos, P.; Aparicio, C.; Melis, E.; Savi, P.; Lupu, F.; Arnout, J.; Dewerchin, M.; Hoylaerts, M.; Herbert, J.; et al. Deficiency or inhibition of Gas6 causes platelet dysfunction and protects mice against thrombosis. Nat. Med. 2001, 7, 215-221. [CrossRef] [PubMed]

78. Lal, I.; Dittus, K.; Holmes, C.E. Platelets, coagulation and fibrinolysis in breast cancer progression. Breast Cancer Res. 2013, 15, 207. [CrossRef] [PubMed]

79. Palumbo, J.S.; Talmage, K.E.; Massari, J.V.; La Jeunesse, C.M.; Flick, M.J.; Kombrinck, K.W.; Jirouskova, M.; Degen, J.L. Platelets and fibrin(ogen) increase metastatic potential by impeding natural killer cell-mediated elimination of tumor cells. Blood 2005, 105, 178-185. [CrossRef] [PubMed]

80. Sharma, D.; Brummel-Ziedins, K.E.; Bouchard, B.A.; Holmes, C.E. Platelets in tumor progression: A host factor that offers multiple potential targets in the treatment of cancer. J. Cell. Physiol. 2014, 229, 1005-1015. [CrossRef] [PubMed]

81. Angelillo-Scherrer, A.; Burnier, L.; Flores, N.; Savi, P.; DeMol, M.; Schaeffer, P.; Herbert, J.M.; Lemke, G.; Goff, S.P.; Matsushima, G.K.; et al. Role of Gas6 receptors in platelet signaling during thrombus stabilization and implications for antithrombotic therapy. J. Clin. Investig. 2005, 115, 237-246. [CrossRef] [PubMed]

82. Mahadevan, D.; Cooke, L.; Riley, C.; Swart, R.; Simons, B.; Della Croce, K.; Wisner, L.; Iorio, M.; Shakalya, K.; Garewal, H.; et al. A novel tyrosine kinase switch is a mechanism of imatinib resistance in gastrointestinal stromal tumors. Oncogene 2007, 26, 3909-3919. [CrossRef] [PubMed]

83. Li, X.Y.; Wen, J.Y.; Jia, C.C.; Wang, T.T.; Li, X.; Dong, M.; Lin, Q.U.; Chen, Z.H.; Ma, X.K.; Wei, L.I.; et al. MicroRNA-34a-5p enhances sensitivity to chemotherapy by targeting AXL in hepatocellular carcinoma MHCC-97L cells. Oncol. Lett. 2015, 10, 2691-2698. [CrossRef] [PubMed]

84. Li, Y.; Jia, L.; Liu, C.; Gong, Y.; Ren, D.; Wang, N.; Zhang, X.; Zhao, Y. Axl as a downstream effector of TGF- $\beta 1$ via PI3K/Akt-PAK1 signaling pathway promotes tumor invasion and chemoresistance in breast carcinoma. Tumour Biol. 2015, 36, 1115-1127. [CrossRef] [PubMed]

85. Hong, C.C.; Lay, J.D.; Huang, J.S.; Cheng, A.L.; Tang, J.L.; Lin, M.T.; Lai, G.M.; Chuang, S.E. Receptor tyrosine kinase AXL is induced by chemotherapy drugs and overexpression of AXL confers drug resistance in acute myeloid leukemia. Cancer Lett. 2008, 268, 314-324. [CrossRef] [PubMed]

86. Park, I.K.; Mundy-Bosse, B.; Whitman, S.P.; Zhang, X.; Warner, S.L.; Bearss, D.J.; Blum, W.; Marcucci, G.; Caligiuri, M.A. Receptor tyrosine kinase Axl is required for resistance of leukemic cells to FLT3-targeted therapy in acute myeloid leukemia. Leukemia 2015, 29, 2382-2389. [CrossRef] [PubMed]

87. Vouri, M.; Croucher, D.R.; Kennedy, S.P.; An, Q.; Pilkington, G.J.; Hafizi, S. Axl-EGFR receptor tyrosine kinase hetero-interaction provides EGFR with access to pro-invasive signalling in cancer cells. Oncogenesis 2016, 5, e266. [CrossRef] [PubMed] 
88. Ghiso, E.; Migliore, C.; Ciciriello, V.; Morando, E.; Petrelli, A.; Corso, S.; De Luca, E.; Gatti, G.; Volante, M.; Giordano, S. YAP-dependent AXL overexpression mediates resistance to EGFR inhibitors in NSCLC. Neoplasia 2017, 19, 1012-1021. [CrossRef] [PubMed]

89. Goyette, M.A.; Duhamel, S.; Aubert, L.; Pelletier, A.; Savage, P.; Thibault, M.P.; Johnson, R.M.; Carmeliet, P.; Basik, M.; Gaboury, L.; et al. The receptor tyrosine kinase AXL is required at multiple steps of the metastatic cascade during HER2-positive breast cancer progression. Cell Rep. 2018, 23, 1476-1490. [CrossRef] [PubMed]

90. Miller, M.A.; Oudin, M.J.; Sullivan, R.J.; Wang, S.J.; Meyer, A.S.; Im, H.; Frederick, D.T.; Tadros, J.; Griffith, L.G.; Lee, H.; et al. Reduced proteolytic shedding of receptor tyrosine kinases is a post-translational mechanism of kinase inhibitor resistance. Cancer Discov. 2016, 6, 382-399. [CrossRef] [PubMed]

91. Lemke, G.; Rothlin, C.V. Immunobiology of the TAM receptors. Nat. Rev. Immunol. 2008, 8, 327-336. [CrossRef] [PubMed]

92. Lemke, G. Biology of the TAM receptors. Cold Spring Harb. Perspect. Biol. 2013, 5, a009076. [CrossRef] [PubMed]

93. Trahtemberg, U.; Mevorach, D. Apoptotic cells induced signaling for immune homeostasis in macrophages and dendritic cells. Front. Immunol. 2017, 8, 1356. [CrossRef] [PubMed]

94. Rothlin, C.V.; Ghosh, S.; Zuniga, E.I.; Oldstone, M.B.; Lemke, G. TAM receptors are pleiotropic inhibitors of the innate immune response. Cell 2007, 131, 1124-1136. [CrossRef] [PubMed]

95. Lu, Q.; Lemke, G. Homeostatic regulation of the immune system by receptor tyrosine kinases of the Tyro 3 family. Science 2001, 293, 306-311. [CrossRef] [PubMed]

96. Qi, N.; Liu, P.; Zhang, Y.; Wu, H.; Chen, Y.; Han, D. Development of a spontaneous liver disease resembling autoimmune hepatitis in mice lacking tyro3, axl and mer receptor tyrosine kinases. PLoS ONE 2013, 8, e66604. [CrossRef] [PubMed]

97. Mukherjee, S.K.; Wilhelm, A.; Antoniades, C.G. TAM receptor tyrosine kinase function and the immunopathology of liver disease. Am. J. Physiol. Gastrointest. Liver Physiol. 2016, 310, G899-G905. [CrossRef] [PubMed]

98. Murata, M. Inflammation and cancer. Environ. Health Prev. Med. 2018, 23, 50. [CrossRef] [PubMed]

99. Lee, E.H.; Kim, E.M.; Ji, K.Y.; Park, A.R.; Choi, H.R.; Lee, H.Y.; Kim, S.M.; Chung, B.Y.; Park, C.H.; Choi, H.J.; et al. Axl acts as a tumor suppressor by regulating LIGHT expression in T lymphoma. Oncotarget 2017, 8, 20645-20655. [CrossRef] [PubMed]

100. Schmidt, T.; Ben-Batalla, I.; Schultze, A.; Loges, S. Macrophage-tumor crosstalk: Role of TAMR tyrosine kinase receptors and of their ligands. Cell. Mol. Life Sci. 2012, 69, 1391-1414. [CrossRef] [PubMed]

101. Lafdil, F.; Chobert, M.N.; Couchie, D.; Brouillet, A.; Zafrani, E.S.; Mavier, P.; Laperche, Y. Induction of Gas6 protein in CCl4-induced rat liver injury and anti-apoptotic effect on hepatic stellate cells. Hepatology 2006, 44, 228-239. [CrossRef] [PubMed]

102. Fourcot, A.; Couchie, D.; Chobert, M.N.; Zafrani, E.S.; Mavier, P.; Laperche, Y.; Brouillet, A. Gas6 deficiency prevents liver inflammation, steatohepatitis, and fibrosis in mice. Am. J. Physiol. Gastrointest. Liver Physiol. 2011, 300, G1043-G1053. [CrossRef] [PubMed]

103. Lafdil, F.; Chobert, M.N.; Deveaux, V.; Zafrani, E.S.; Mavier, P.; Nakano, T.; Laperche, Y.; Brouillet, A. Growth arrest-specific protein 6 deficiency impairs liver tissue repair after acute toxic hepatitis in mice. J. Hepatol. 2009, 51, 55-66. [CrossRef] [PubMed]

104. Burnier, L.; Saller, F.; Kadi, L.; Brisset, A.C.; Sugamele, R.; Baudino, L.; Bono, F.; Herbert, J.-M.; Carmeliet, P.; Schapira, M.; et al. Gas6 deficiency in recipient mice of allogeneic transplantation alleviates hepatic graft-versus-host disease. Blood 2010, 115, 3390-3397. [CrossRef] [PubMed]

105. Llacuna, L.; Barcena, C.; Bellido-Martin, L.; Fernandez, L.; Stefanovic, M.; Mari, M.; Garcia-Ruiz, C.; Fernandez-Checa, J.C.; Garcia de Frutos, P.; Morales, A. Growth arrest-specific protein 6 is hepatoprotective against murine ischemia/reperfusion injury. Hepatology 2010, 52, 1371-1379. [CrossRef] [PubMed]

106. Matthews, A.L.; Noy, P.J.; Reyat, J.S.; Tomlinson, M.G. Regulation of A disintegrin and metalloproteinase (ADAM) family sheddases ADAM10 and ADAM17: The emerging role of tetraspanins and rhomboids. Platelets 2017, 28, 333-341. [CrossRef] [PubMed]

107. Khokha, R.; Murthy, A.; Weiss, A. Metalloproteinases and their natural inhibitors in inflammation and immunity. Nat. Rev. Immunol. 2013, 13, 649-665. [CrossRef] [PubMed] 
108. Peschon, J.J.; Slack, J.L.; Reddy, P.; Stocking, K.L.; Sunnarborg, S.W.; Lee, D.C.; Russell, W.E.; Castner, B.J.; Johnson, R.S.; Fitzner, J.N.; et al. An essential role for ectodomain shedding in mammalian development. Science 1998, 282, 1281-1284. [CrossRef] [PubMed]

109. Yabkowitz, R.; Meyer, S.; Black, T.; Elliott, G.; Merewether, L.A.; Yamane, H.K. Inflammatory cytokines and vascular endothelial growth factor stimulate the release of soluble tie receptor from human endothelial cells via metalloprotease activation. Blood 1999, 93, 1969-1979. [PubMed]

110. Wyble, C.W.; Hynes, K.L.; Kuchibhotla, J.; Marcus, B.C.; Hallahan, D.; Gewertz, B.L. TNF- $\alpha$ and IL-1 upregulate membrane-bound and soluble E-selectin through a common pathway. J. Surg. Res. 1997, 73, 107-112. [CrossRef] [PubMed]

111. Becker, J.C.; Dummer, R.; Hartmann, A.A.; Burg, G.; Schmidt, R.E. Shedding of ICAM-1 from human melanoma cell lines induced by IFN- $\gamma$ and tumor necrosis factor- $\alpha$. Functional consequences on cell-mediated cytotoxicity. J. Immunol. 1991, 147, 4398-4401. [PubMed]

112. Dethlefsen, S.M.; Raab, G.; Moses, M.A.; Adam, R.M.; Klagsbrun, M.; Freeman, M.R. Extracellular calcium influx stimulates metalloproteinase cleavage and secretion of heparin-binding EGF-like growth factor independently of protein kinase C. J. Cell. Biochem. 1998, 69, 143-153. [CrossRef]

113. Arribas, J.; Massague, J. Transforming growth factor- $\alpha$ and $\beta$-amyloid precursor protein share a secretory mechanism. J. Cell Biol. 1995, 128, 433-441. [CrossRef] [PubMed]

114. Singh, R.J.; Mason, J.C.; Lidington, E.A.; Edwards, D.R.; Nuttall, R.K.; Khokha, R.; Knauper, V.; Murphy, G.; Gavrilovic, J. Cytokine stimulated vascular cell adhesion molecule-1 (VCAM-1) ectodomain release is regulated by TIMP-3. Cardiovasc. Res. 2005, 67, 39-49. [CrossRef] [PubMed]

115. Walev, I.; Vollmer, P.; Palmer, M.; Bhakdi, S.; Rose-John, S. Pore-forming toxins trigger shedding of receptors for interleukin 6 and lipopolysaccharide. Proc. Natl. Acad. Sci. USA 1996, 93, 7882-7887. [CrossRef] [PubMed]

116. Borrell-Pages, M.; Rojo, F.; Albanell, J.; Baselga, J.; Arribas, J. TACE is required for the activation of the EGFR by TGF- $\alpha$ in tumors. EMBO J. 2003, 22, 1114-1124. [CrossRef] [PubMed]

117. Brachmann, R.; Lindquist, P.B.; Nagashima, M.; Kohr, W.; Lipari, T.; Napier, M.; Derynck, R. Transmembrane TGF- $\alpha$ precursors activate EGF/TGF- $\alpha$ receptors. Cell 1989, 56, 691-700. [CrossRef]

118. Horiuchi, K. A brief history of tumor necrosis factor $\alpha$-converting enzyme: An overview of ectodomain shedding. Keio J. Med. 2013, 62, 29-36. [CrossRef] [PubMed]

119. Tanida, S.; Joh, T.; Itoh, K.; Kataoka, H.; Sasaki, M.; Ohara, H.; Nakazawa, T.; Nomura, T.; Kinugasa, Y.; Ohmoto, H.; et al. The mechanism of cleavage of EGFR ligands induced by inflammatory cytokines in gastric cancer cells. Gastroenterology 2004, 127, 559-569. [CrossRef] [PubMed]

120. Higashiyama, S.; Nanba, D. ADAM-mediated ectodomain shedding of HB-EGF in receptor cross-talk. Biochim. Biophys. Acta 2005, 1751, 110-117. [CrossRef] [PubMed]

121. Nanba, D.; Mammoto, A.; Hashimoto, K.; Higashiyama, S. Proteolytic release of the carboxy-terminal fragment of proHB-EGF causes nuclear export of PLZF. J. Cell Biol. 2003, 163, 489-502. [CrossRef] [PubMed]

122. Jones, F.E. HER4 intracellular domain (4ICD) activity in the developing mammary gland and breast cancer. J. Mammary Gland Biol. Neoplasia 2008, 13, 247-258. [CrossRef] [PubMed]

123. Linggi, B.; Cheng, Q.C.; Rao, A.R.; Carpenter, G. The ErbB-4 s80 intracellular domain is a constitutively active tyrosine kinase. Oncogene 2006, 25, 160-163. [CrossRef] [PubMed]

124. Lu, Y.; Wan, J.; Yang, Z.; Lei, X.; Niu, Q.; Jiang, L.; Passtoors, W.M.; Zang, A.; Fraering, P.C.; Wu, F. Regulated intramembrane proteolysis of the AXL receptor kinase generates an intracellular domain that localizes in the nucleus of cancer cells. FASEB J. 2017, 31, 1382-1397. [CrossRef] [PubMed]

125. Foveau, B.; Ancot, F.; Leroy, C.; Petrelli, A.; Reiss, K.; Vingtdeux, V.; Giordano, S.; Fafeur, V.; Tulasne, D. Down-regulation of the met receptor tyrosine kinase by presenilin-dependent regulated intramembrane proteolysis. Mol. Biol. Cell 2009, 20, 2495-2507. [CrossRef] [PubMed]

126. Marron, M.B.; Singh, H.; Tahir, T.A.; Kavumkal, J.; Kim, H.Z.; Koh, G.Y.; Brindle, N.P. Regulated proteolytic processing of Tie1 modulates ligand responsiveness of the receptor-tyrosine kinase Tie2. J. Biol. Chem. 2007, 282, 30509-30517. [CrossRef] [PubMed]

127. Nami, B.; Wang, Z. HER2 in Breast Cancer Stemness: A Negative Feedback Loop towards Trastuzumab Resistance. Cancers 2017, 9. [CrossRef] 
128. Wang, J.; Willumsen, N.; Zheng, Q.; Xue, Y.; Karsdal, M.A.; Bay-Jensen, A.C. Bringing cancer serological diagnosis to a new level: Focusing on HER2, protein ectodomain shedding and neoepitope technology. Future Oncol. 2013, 9, 35-44. [CrossRef] [PubMed]

129. Segatto, O.; King, C.R.; Pierce, J.H.; Di Fiore, P.P.; Aaronson, S.A. Different structural alterations upregulate in vitro tyrosine kinase activity and transforming potency of the erbB-2 gene. Mol. Cell. Biol. 1988, 8, 5570-5574. [CrossRef] [PubMed]

130. Bellan, M.; Pogliani, G.; Marconi, C.; Minisini, R.; Franzosi, L.; Alciato, F.; Magri, A.; Avanzi, G.C.; Pirisi, M.; Sainaghi, P.P. Gas6 as a putative noninvasive biomarker of hepatic fibrosis. Biomark. Med. 2016, 10, 1241-1249. [CrossRef] [PubMed]

131. Uehara, S.; Fukuzawa, Y.; Matuyama, T.; Gotoh, K. Role of Tyro3, Axl, and Mer Receptors and Their Ligands (Gas6, and Protein S) in Patients with Hepatocellular Carcinoma. J. Cancer Ther. 2017, 8, 112-113. [CrossRef]

132. Kohga, K.; Takehara, T.; Tatsumi, T.; Miyagi, T.; Ishida, H.; Ohkawa, K.; Kanto, T.; Hiramatsu, N.; Hayashi, N. Anticancer chemotherapy inhibits MHC class I-related chain a ectodomain shedding by downregulating ADAM10 expression in hepatocellular carcinoma. Cancer Res. 2009, 69, 8050-8057. [CrossRef] [PubMed]

133. Zhang, W.; Liu, S.; Liu, K.; Wang, Y.; Ji, B.; Zhang, X.; Liu, Y. A disintegrin and metalloprotease (ADAM)10 is highly expressed in hepatocellular carcinoma and is associated with tumour progression. J. Int. Med. Res. 2014, 42, 611-618. [CrossRef] [PubMed]

134. Reichl, P.; Fang, M.; Starlinger, P.; Staufer, K.; Nenutil, R.; Muller, P.; Greplova, K.; Valik, D.; Dooley, S.; Brostjan, C.; et al. Multicenter analysis of soluble Axl reveals diagnostic value for very early stage hepatocellular carcinoma. Int. J. Cancer 2015, 137, 385-394. [CrossRef] [PubMed]

135. Dengler, M.; Staufer, K.; Huber, H.; Stauber, R.; Bantel, H.; Weiss, K.H.; Starlinger, P.; Pock, H.; Kloters-Plachky, P.; Gotthardt, D.N.; et al. Soluble Axl is an accurate biomarker of cirrhosis and hepatocellular carcinoma development: Results from a large scale multicenter analysis. Oncotarget 2017, 8, 46234-46248. [CrossRef] [PubMed]

136. Schoenberg, M.B.; Bucher, J.N.; Vater, A.; Bazhin, A.V.; Hao, J.; Guba, M.O.; Angele, M.K.; Werner, J.; Rentsch, M. Resection or transplant in early hepatocellular carcinoma. Dtsch. Arztebl. Int. 2017, 114, 519-526. [CrossRef] [PubMed]

137. Altekruse, S.F.; McGlynn, K.A.; Reichman, M.E. Hepatocellular carcinoma incidence, mortality, and survival trends in the United States from 1975 to 2005. J. Clin. Oncol. 2009, 27, 1485-1491. [CrossRef] [PubMed]

138. Batlle, M.; Recarte-Pelz, P.; Roig, E.; Castel, M.A.; Cardona, M.; Farrero, M.; Ortiz, J.T.; Campos, B.; Pulgarin, M.J.; Ramirez, J.; et al. AXL receptor tyrosine kinase is increased in patients with heart failure. Int. J. Cardiol. 2014, 173, 402-409. [CrossRef] [PubMed]

139. Kariolis, M.S.; Miao, Y.R.; Jones, D.S., 2nd; Kapur, S.; Mathews, I.I.; Giaccia, A.J.; Cochran, J.R. An engineered Axl 'decoy receptor' effectively silences the Gas6-Axl signaling axis. Nat. Chem. Biol. 2014, 10, 977-983. [CrossRef] [PubMed]

140. Kariolis, M.S.; Miao, Y.R.; Diep, A.; Nash, S.E.; Olcina, M.M.; Jiang, D.; Jones, D.S., 2nd; Kapur, S.; Mathews, I.I.; Koong, A.C.; et al. Inhibition of the GAS6/AXL pathway augments the efficacy of chemotherapies. J. Clin. Investig. 2017, 127, 183-198. [CrossRef] [PubMed]

141. Haider, C.; Hnat, J.; Wagner, R.; Huber, H.; Timelthaler, G.; Grubinger, M.; Coulouarn, C.; Schreiner, W.; Schlangen, K.; Sieghart, W.; et al. Transforming growth factor- $\beta$ and Axl induce CXCL5 and neutrophil recruitment in hepatocellular carcinoma. Hepatology 2018. [CrossRef] [PubMed]

142. Zhou, S.L.; Zhou, Z.J.; Hu, Z.Q.; Huang, X.W.; Wang, Z.; Chen, E.B.; Fan, J.; Cao, Y.; Dai, Z.; Zhou, J. Tumor-associated neutrophils recruit macrophages and T-regulatory cells to promote progression of hepatocellular carcinoma and resistance to sorafenib. Gastroenterology 2016, 150, 1646-1658. [CrossRef] [PubMed]

(C) 2018 by the authors. Licensee MDPI, Basel, Switzerland. This article is an open access article distributed under the terms and conditions of the Creative Commons Attribution (CC BY) license (http:/ / creativecommons.org/licenses/by/4.0/). 